\section{Vitamin D deficiency in HIV-infected individuals: one more risk factor for bone loss and cardiovascular disease?}

\author{
Deficiência de vitamina D em indivíduos infectados pelo HIV: \\ mais um fator de risco para perda óssea e doença cardiovascular?
}

Tereza Conrado', Demócrito de Barros Miranda-Filho', Francisco Bandeira²

\section{SUMMARY}

${ }^{1}$ Departamento de Medicina Interna, Divisão de Doenças Infecciosas, Universidade de Pernambuco (UPE), Recife, PE, Brasil ${ }^{2}$ Divisão de Endocrinologia, Departamento de Medicina, Hospital Agamenon Magalhães, Sistema Único de Saúde (SUS), UPE, Faculdade de Ciências Médicas, Recife, PE, Brasil

Correspondence to: Tereza Conrado Rua Frei Leandro, 70/502 51011-600 - Recife, PE, Brasil terezaconrado@hotmail.com
The epidemiological profile of the HIV virus has undergone substantial modifications with advances in antiretroviral therapy. There has been a sharp decline in morbi-mortality levels of HIVinfected patients, which has resulted in higher survival rates. The HIV seropositive population is living longer and more exposed to chronic complications caused by the disease itself and the prolonged use of antiretrovirals. Initially, metabolic alterations were reported, increasing cardiovascular disease risk. Subsequently, damage on bone metabolism was related. Vitamin $D$ insufficiency has now reached epidemic proportions, even in healthy individuals living in the tropics. Recent data suggest the hypovitaminosis D association with metabolic syndrome, immune diseases, diabetes and hypertension. Little is known regarding the effects of HIV/Aids and its treatment on the metabolism of vitamin D. In HIV-positive patients, factors linked to the virus itself and the use of antiretrovirals may be added to the other causes of hypovitaminosis D. Arq Bras Endocrinol Metab. 2010;54(2):118-22

\section{Keywords}

Vitamin D deficiency; HIV; vitamin D; ART

\section{SUMÁRIO}

O perfil epidemiológico da infecção pelo vírus HIV vem sofrendo grandes modificações com os avanços na terapia antirretroviral. Houve uma queda expressiva na morbi-mortalidade do paciente infectado pelo HIV e, por conseguinte, aumento da sobrevida. A população soropositiva está envelhecendo e mais exposta às complicações da cronificação da doença e ao uso prolongado dos antirretrovirais. Inicialmente foram descritas alterações metabólicas que contribuem para um aumento no risco de doença cardiovascular. Em seguida, surgiram relatos de danos ao metabolismo ósseo. A deficiência de vitamina $D$ tem atingido proporções epidêmicas envolvendo até mesmo indivíduos saudáveis em regiões tropicais. Dados recentes sugerem sua associação com síndrome metabólica, doenças imunes, diabetes e hipertensão. A doença HIV/Aids e a ação dos antirretrovirais no metabolismo da vitamina $D$ ainda permanecem pouco conhecidas. Em pacientes HIV positivos, fatores ligados ao próprio vírus e ao uso dos antirretrovirais podem estar adicionados às demais causas de hipovitaminose D. Arq Bras Endocrinol Metab. 2010;54(2):118-22

Descritores

Deficiência de vitamina D; HIV; vitamina D; TARV

\section{INTRODUCTION}

$\mathrm{T}$ hroughout the world, 33 million people have been infected to date by the human immunodeficiency virus (HIV) and, in 2007 alone, 2 million people died as a result of Aids. In Brazil, there are an estimated 730 thousand HIV-positive patients, representing one third of all registered cases in Latin America $(1,2)$. However, the sociodemographic profile of this infection has un- 
dergone a number of modifications. Over the previous few years there has been an increase in the number of cases amongst heterosexual men and a predominance of this form of transmission amongst women (3). Currently, the chances of men contracting this disease are 1.5 time greater than women, as compared to the last decade, when it was 15 times greater. This tendency of Aids towards gender parity has had a profound impact on the health of women all over the world $(1,2)$.

Apart from affecting more women, HIV-positive patients have also experienced a greater chance of survival due to the advent of ART (antiretroviral therapy), coupled with an increased knowledge of the infection. The female seropositive population is now growing older and is consequently more exposed to chronic degenerative diseases brought on by prolonged exposure to the HIV virus and antiretroviral therapy. Initially, metabolic abnormalities were reported such as dyslipidemia, insulin resistance and lipodystrophy, which all contribute to the increased risk of cardiovascular disease (CVD). Subsequently, reports emerged of damage to the bone metabolism (4-7).

In association with these factors, menopausal women experience a period of hormone decline, progressively reducing the effects of estrogen protection on bone metabolism and CVD $(8,9)$. According to Pernerstorfer, metabolic abnormalities resulting from ART are more pronounced in women, suggesting that, after they begin treatment, infected patients lose part of their natural protection against atherosclerosis (9).

The introduction of ART has had a profound impact by reducing the viral load and reconstituting the immune system of HIV/Aids patients. Thus, a significant impact has been observed on the natural history of the infection, represented by the considerable decline in morbi-mortality associated with the disease. The treatment is a complex therapeutic regimen made up of a combination of at least 3 drugs that include the use of two nucleoside-analogue reverse-transcriptase inhibitors (NRTI) and one from another class, which is usually a non-nucleoside reverse-transcriptase inhibitor (NNRTI) or a (PI) protease inhibitor (10).

Another important issue has been the growing pauperization of this epidemic and its consequent importance regarding nutritional deficiency. Currently, more than $2 / 3$ of the most recently infected individuals live in extremely poor regions of the world, where there is a high prevalence of nutritional deficiency. A lack of macronutrients has been associated with an increasing number of clinical manifestations and a rise in Aids-related mortality $(1,11)$. Furthermore, studies have also revealed how the beneficial effects of being well-nourished with the necessary vitamin supplements can lead to an improvement in the immune systems of HIV-positive patients $(11,12)$.

With regard specifically to vitamin D deficiency, much attention has been focused on its importance as a steroid hormone and its properties as an immunomodulator since the vitamin D nuclear receptor (VDR) was discovered, during the 1980s, in various cells, especially those in the immune system such as $\mathrm{T}$ and B lymphocytes, monocytes and dendritic cells. Before the advent of antibiotics, vitamin $\mathrm{D}$ was used in the treatment of bacterial infections (11-15). Many in vitro experiments confirm the action of its active form, $1,25(\mathrm{OH})_{2} \mathrm{D}$, as a potent modulator of the immune system as well as its important role in calcium homeostasis. In addition, in vivo, a lack of vitamin $\mathrm{D}$ is associated with macrophage dysfunction and bacterial infection $(11,13)$. Despite these advances, much remains to be clarified regarding the role of vitamin D in HIV infection and how its deficiency may affect the progression of the disease (11-13). Low levels of vitamin D and vitamin D receptor (VDR) polymorphism have been associated with low CD4, immune activity and the progression of Aids $(11,13,16)$.

Currently, vitamin D is recognized as a complex, pluripotent hormone, and its deficiency has now gone beyond the simple concept of causing rickets and osteomalacia. Much evidence has associated it to the metabolic syndrome, diabetes, immune diseases, high blood pressure and cancer $(14,15,17-20)$. Recently, vitamin D has been suggested as an emergent biomarker for CVD (21). However, the exact mechanism that would explain the multiple effects of vitamin $\mathrm{D}$ on different tissues is still unknown. The only common factor is that the vitamin $\mathrm{D}$ receptor has been discovered in various tissues such as those of the pancreas, the smooth muscle of the blood vessels and the cardiac cells, and in the renin-angiotensin axis $(17,20)$.

Vitamin D is obtained in its natural form by exposing the skin to sun rays that converts 7-dehydrocholesterol (pro-vitamin D3) into cholecalciferol (vitamin D3) through which the bloodstream passes, where it joins the D-binding protein (VDBP) and is transported to the liver. The second source of vitamin $\mathrm{D}$ is via oral intake, through the transformation of ergosterol (vitamin $\mathrm{D}_{2}$ ) in plants and fungi. Vitamins $\mathrm{D}_{3}$ and $\mathrm{D}_{2}$, 
are both metabolized in the liver to 25 -hydroxicholecalciferol $[(25(\mathrm{OH}) \mathrm{D}]$ and are transformed in the kidneys into its active form, 1,25 dihydroxyvitamin $\mathrm{D}$ $\left[1,25(\mathrm{OH})_{2} \mathrm{D}\right]$, which is a steroid hormone vital for calcium and bone metabolism (Figure 1). Other factors such as the seasons of the year, latitude, time of day, skin pigmentation, aging and the use of sun blocks may all influence the cutaneous production of vitamin D $(14,15,22,23)$.

In healthy adults, vitamin $\mathrm{D}$ deficiency sets in in a subtle manner, with mild hypocalcemia, and secondary hyperparathyroidism, causing trabecular bone loss and a thinning of the cortical bone, leading to an increased risk of osteoporosis and fractures $(15,22)$. Before antiretroviral treatment was introduced, few studies had indicated that bone metabolism was affected in HIVpositive patients, although it has recently been confirmed that infected patients present a higher risk of low bone mass and osteoporosis. Despite the fact that that was initially attributed to the use of these medications, it was later confirmed that its origins were due to a series of factors, one of the main ones being metabolic dysfunction of vitamin $\mathrm{D}(7,8,24)$.

In HIV-positive patients, other factors linked to the virus itself and to the use of antiretrovirals can be considered as additional causes of hypovitaminosis $\mathrm{D}$, and therefore regarded as a threat to the general population, such as poor nutrition, skin pigmentation, aging and inadequate sun exposure. A number of mechanisms are proposed to explain this deficiency in HIV-positive patients (Figure 2): a) the virus itself decreases vitamin D levels through the action of proinflammatory cytokines such as TNF- $\alpha$ (Tumor necrosis factor- $\alpha$ ), inhibiting renal hydroxylation; b) the consumption of $25(\mathrm{OH}) \mathrm{D}$ by the macrophages and lymphocytes as the disease progresses; and c) the type of antiretrovirals used. PIs (protease inhibitors) block the hydroxylation of $25(\mathrm{OH}) \mathrm{D}$ (25-hydroxycholecalciferol) and the bioactivation of $1,25(\mathrm{OH})_{2}(1,25$ dihydroxyvitamin $\mathrm{D})$ in the kidneys $(11,16,17)$, while NNRTIs (non-nucleoside reversetranscriptase inhibitors) increase the catabolism of 25 $(\mathrm{OH}) \mathrm{D}$ and $1,25(\mathrm{OH})_{2} \mathrm{D}(25)$.

Vitamin D synthesis and metabolism

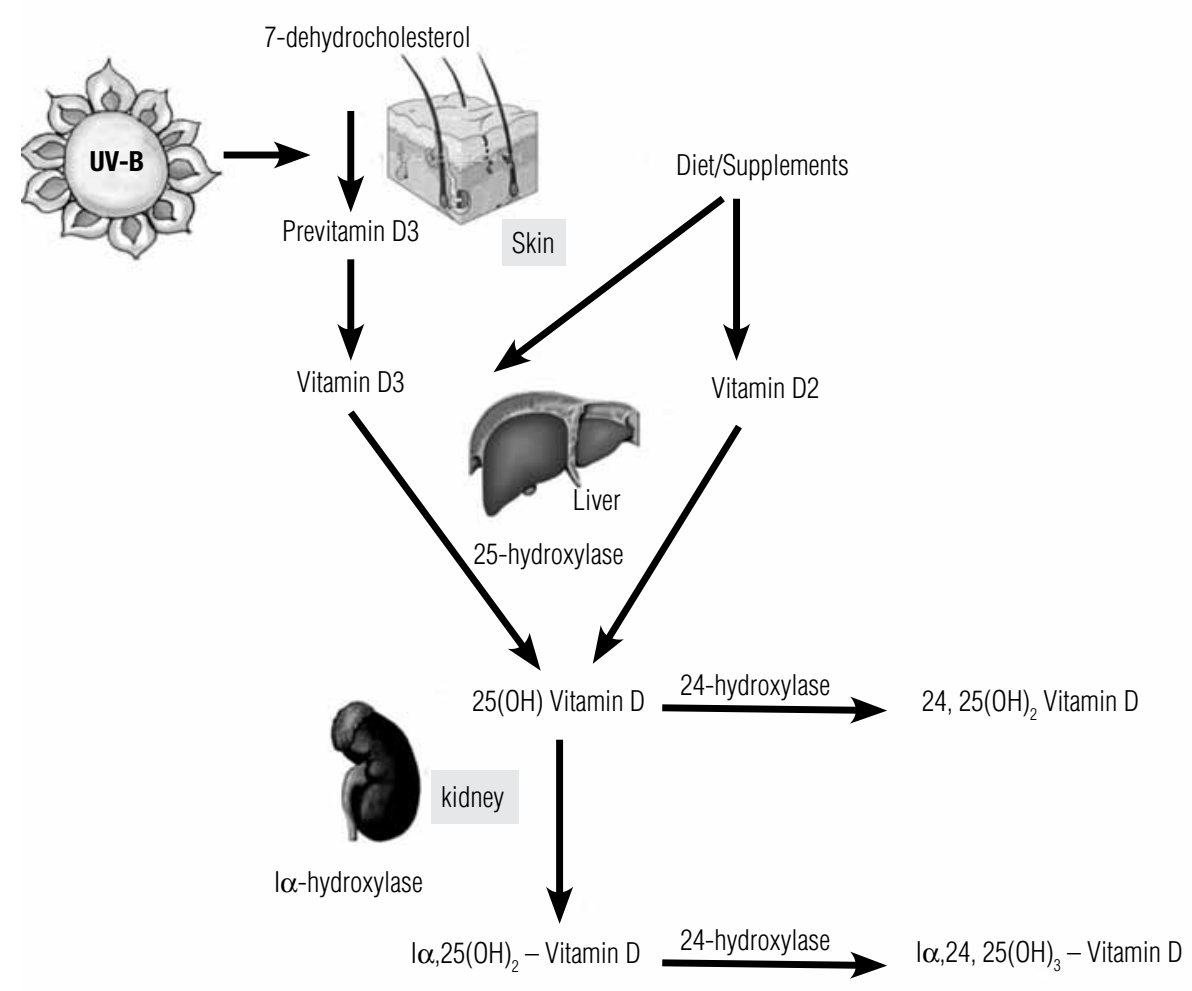

Figure 1. 7-Dehydrocholesterol (pro-vitamin D3) during sun exposure (UVB), in the skin, is converted to previtamin $\mathrm{D}_{3}$. Vitamins $\mathrm{D}_{3}$ (cholecalciferol) and $\mathrm{D}_{2}$ (ergosterol) are both metabolized in the liver to 25-hydroxicholecalciferol [(25(OH)D] and are transformed in the kidneys into its active form, 1,25 dihydroxyvitamin $\mathrm{D}\left[1,25(\mathrm{OH})_{2} \mathrm{D}\right]$. Inactivation of vitamin $\mathrm{D}$ metabolites occurs mainly by renal 24 -hydroxylation. 
Possible mechanisms of vitamin D deficiency in HIV-infected individuals

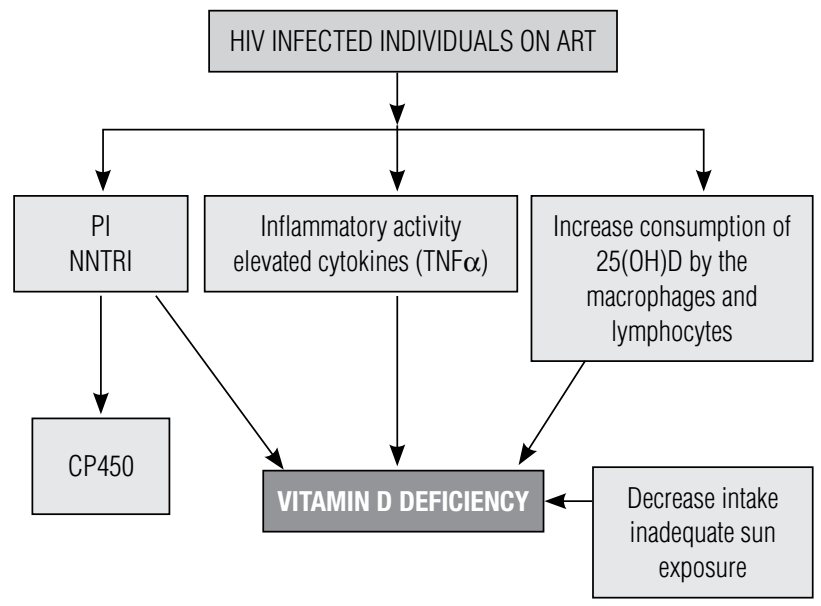

Figure 2. HIV: human immunodeficiency virus; ART: antiretroviral therapy; NNRTI: non-nucleoside reverse-transcriptase inhibitor; PI: protease inhibitor; TNF- $\alpha$ : tumor necrosis factor- $\alpha$ ); 25(OH)D: 25-hydroxycholecalciferol; CP450: cytochrome P450.

A study carried out in the Netherlands with HIVpositive patients of both sexes reported a $58.1 \%$ prevalence of vitamin $\mathrm{D}$ deficiency in women with a mean age of 36.5 years, using reference levels for serum $25(\mathrm{OH}) \mathrm{D}$ of $10-14 \mathrm{ng} / \mathrm{mL}$ for winter and summer, respectively (25). Similar results were reported in a US population of seropositive teenagers and young adults, employing a cut-off for serum $25(\mathrm{OH}) \mathrm{D}$ of $15 \mathrm{ng} / \mathrm{mL}$, demonstrating a prevalence of $87 \%$ of hypovitaminosis D (12). Seminari, in Italy, found serum 25(OH)D levels of less than $18 \mathrm{ng} / \mathrm{mL}$ in $81,25 \%$ of the patients, aged 41 years, who were on ART and had been losing bone (24). Similar prevalence $(86 \%)$ was described by Aparicio and cols. (26) when evaluating Spanish infected males, using reference levels of serum $25(\mathrm{OH})$ D less than $10 \mathrm{ng} / \mathrm{mL}$ (26). Rodriguez, in the US, also reported hypovitaminosis $\mathrm{D}$ in $74.4 \%$ of infected adults aged 46 years, using reference levels of serum $25(\mathrm{OH})$ D less than $32 \mathrm{ng} / \mathrm{mL}(27)$.

There is no consensus on the ideal serum concentration of $25(\mathrm{OH}) \mathrm{D}$ and there are many suggested values for setting the lower limit of normality from 20 to as much 37 $\mathrm{ng} / \mathrm{mL}(14,15,22,23)$. Therefore the level of vitamin D should be the one that does not induce a rise in parathyroid hormone $(\mathrm{PTH})$, and the optimal serum $25(\mathrm{OH}) \mathrm{D}$ concentrations have yet to be established $(14,15,22,23)$. It is not surprising that discordant results are obtained because these laboratories use substantially different methodology for measurement of $25(\mathrm{OH}) \mathrm{D}$, which, to this time, has not been standardized $(14,15,22,23)$.
In healthy populations, clinical evidence based on epidemiological studies has demonstrated an association between vitamin $\mathrm{D}$ deficiency and an overall increased risk of mortality, based on NHANES-III - Third National Health and Nutrition Examination Survey (18). Further evidence that hypovitaminosis D increases the risk of CVD has appeared in a recent nested case-control study, in which men and couples were studied over a ten-year period for classical risk factors of CVD, with detected levels less than $30 \mathrm{ng} / \mathrm{mL}$ of serum $25(\mathrm{OH})$ $\mathrm{D}$ being associated with a significant increase in myocardial infarction (19).

There are very few reports for seropositive patients on the consequences of hypovitaminosis D on the lipid and glucose metabolism, although it is known that there is an association between ART and complications of fat redistribution (loss of peripheral fat and increased central obesity), insulin resistance and dyslipidemia $(4,5)$. Recently, similar alterations have also been described in healthy patients with vitamin D deficiency $(14,15,17,20,28)$.

In NHANES-III, Ford followed-up 8,421 healthy men and women and described an inverse association between serum 25(OH)D levels and the metabolic syndrome, caused mainly by hyperglycemia, hypertriglyceridemia and abdominal obesity (28). In a UK study, 524 randomized, healthy individuals were followed-up for a 10 -year period. A negative association was observed between the serum levels of $25(\mathrm{OH}) \mathrm{D}$ and an increase in glycemia and insulin resistance, possibly explained by the action of VDR in the pancreatic $\beta$ cells and in the insulin activation receptors, or indirectly by the increased number of inflammatory cytokines resulting from the decreased levels of vitamin D (29).

Current data from the Framingham Offspring Study cohort evaluated 1,739 patients without renal disease or previous CVD and described an association between vitamin $\mathrm{D}$ deficiency and an increased risk of CVD, especially in hypertensive individuals with serum $25(\mathrm{OH})$ D levels of less than $15 \mathrm{ng} / \mathrm{mL}$, who had a two-fold risk of a cardiovascular event (17).

The results of the DAD study, which enrolled more than 22,000 HIV-positive patients, indicated a high frequency of hypertension, smoking, dyslipidemia and diabetes, in which ART was associated with a $26 \%$ increase in the relative risk levels of myocardial infarction for each year it was taken (6). Besides the traditional risk factors for CVD, these individuals are also exposed to other risk factors, including the disease itself, the direct effect of the virus on blood vessels, inflammation and complications from the prolonged use of antiretroviral therapy $(5,6)$. 
Together with this chain of possible events, vitamin D deficiency may also be included as one more cause of bone loss, the metabolic syndrome, dyslipidemia and an increased risk of CVD. These results are of particular relevance for HIV-positive women on ART. Not only are they likely to stimulate the progression of the disease through vitamin $\mathrm{D}$ deficiency, but also add one more risk factor to the prolonged use of antiretroviral therapy.

In conclusion, considering that vitamin $\mathrm{D}$ deficiency has been suggested as a possible risk condition for metabolic and cardiovascular events, the increased prevalence of this clinical condition in this population indicates the need for prevention. It is too early to identify the groups at greatest risk for which these measures would be required. In this context, vitamin $\mathrm{D}$ supplementation becomes necessary and/or sun exposure when the measurement of serum $25(\mathrm{OH}) \mathrm{D}$ is not feasible. Additional observational studies are needed to confirm the associations between vitamin D status and HIV disease progression and intervention studies will be necessary to define the benefits of vitamin $\mathrm{D}$ in the cardiovascular system and endocrine metabolism in the HIV-infected patient.

Disclosure: no potential conflict of interest relevant to this article was reported.

\section{REFERENCES}

1. UNAIDS. Aids Epidemic Update 2008. Available from: http:// www.unaids.org. htm (Access May 15, 2009).

2. MINISTÉRIO DA SAÚDE. Boletim Epidemiológico - Aids e DST, Janeiro a Junho de 2008, Ano V, n. 1, p. 1-36. Brasília, Dezembro, 2008. Available from: http:// www.aids.gov.br. htm (Access May $15,2009)$.

3. Dourado I, Veras MAS, Barreira D, Brito AM. Tendências da epidemia de Aids no Brasil após a terapia antirretroviral. Rev Saude Publica. 2006;40(S):9-17.

4. Carr A. HIV lipodystrophy: risk factors, pathogenesis, diagnosis and management. AIDS. 2003;1:(S)141-48.

5. Grinspoon SK, Grunfeld C, Kotler DP, Currier JS, Lundgren JE, Dubé MP, et al. State of the Science Conference Initiative to Decrease Cardiovascular Risk and Increase Quality of Care for Patients Living With HIV/AIDS. Circulation. 2008;118(2):198-210.

6. DAD Study Group, Friis-Møller N, Reiss P, Sabin CA, Weber R, Monforte A, El-Sadr W, et al. Class of antiretroviral drugs and the risk of myocardial infarction. N Engl J Med. 2007;356(17):1723-35.

7. Madeddu G, Spanu A, Solinas P, Calia GM, Lovigu C, Chessa F, et al. Bone mass loss and vitamin D metabolism impairment in HIV patients receiving highly active antiretroviral therapy. $\mathrm{Q} \mathrm{J} \mathrm{Nucl}$ Med Mol Imaging. 2004;48:39-48.

8. Yin M, Dobkin J, Brudney K, Becker C, Zadel JL, Manandhar M. Bone mass and mineral metabolism in HIV+ postmenopausal women. Osteoporosis Int. 2005;16:1345-52.

9. Pernerstorfer-Schoen H, Jilma B, Perschler A, Wichlas S, Schindler K, Schindl A, et al. Sex differences in HAART-associated dyslipidaemia. AIDS. 2001;15:725-34.
10. MINISTÉRIO DA SAÚDE. Secretaria de Vigilância em Saúde, Programa Nacional de DST e Aids. Recomendações para terapia anti-retroviral em adultos e adolescentes infectados pelo HIV 2008. Documento preliminar 2007. Available from: www.saude. rio.rj.gov.br/media/dstaids_consenso_adulto_2008.pdf

11. Villamor E. A potential role for vitamin D on HIV infection? Nutr Rev. 2006;64:226-33.

12. Stephensen CB, Marquis GS, Kruzich LA, Douglas SD, Aldrovandi GM, Wilson CM. Vitamin D status in adolescentes and young adults with HIV infection. Am J Clin Nutr. 2006;83:1135-41.

13. Haug CJ, Aukrust $P$, Haug E, Mørkrid L, Müller F, Froland SS. Deficiency 1,25 didroxi vitamin D3 in human immunodeficiency hyperactivity and only minor changes in calcium homeostasis. $J$ Clin Endocrinol Metab. 1998;83:3832-8.

14. Holick MF. High prevalence of vitamin D inadequacy and implications for health. Mayo Clin Proc. 2006;81:353-73.

15. Holick MF. Vitamin D deficiency. N Engl J Med. 2007;357:266-81.

16. Cozzolino M, Vidal M, Arcidiacono MV, Tebas P, Yarasheski KE, Dusso AS. HIV protease inhibitor impairs vitamin D bioactivation 1,25-dihydroxyvitamin D. AIDS. 2003;17:513-20.

17. Wang TJ, Pencina MJ, Booth SL, Jacques PF, Benjamin EJ, Ingelsson $E$, et al. Vitamin $D$ deficiency and risk of cardiovascular disease. Circulation. 2008;117:503-11.

18. Melamed ML, Michos ED, Post W, Brad A. 25-hydroxyvitamin D levels and the risk of mortality in the general population. Arch Intern Med. 2008;168:1629-37.

19. Giovannucci E, Liu Y, Hollis BW, Rimm EB. 25-hydroxyvitamin D and risk of myocardial infarction in men. A prospective study. Arch Intern Med. 2008;168:1174-80.

20. Kremer R, Campbell PP, Reinhard T, Gilsanz V. Vitamin D status and its relationship to body fat, final height, and peak bone mass in young women. J Clin Endocrinol Metab. 2009;94:67-73.

21. Zittermann A, Frisch S, Berthold HK, Gotting C, Kuhn J, Kleesiek K, et al. Vitamin D supplementation enhances the beneficial effects of weight loss on cardiovascular disease risk markers. Am J Clin Nutr. 2009;89:1321-7.

22. Bandeira F, Griz L, Dreyer P, Bandeira C, Eufrazino C, Freese E. Vitamin D Deficiency: a global perspective. Arq Bras Endocrinol Metab. 2006;50:640-5.

23. Bandeira F, Griz L, Freese E, Lima DC, Thé AC, Diniz ET, et al. Vitamin $D$ deficiency and its relationship with bone mineral density among postmenopausal women living in the tropics. Arq Bras Endocrinol Metab. 2010;54(2):227-32.

24. Seminari E, Samaras K, Wand H, Law M, Emery S, Cooper D, et al. Osteoprotegerin and bone turnover markers in heavily pretreated HIV-infected patients. HIV Med. 2005;6:145-50.

25. Van Den Bout-Van Den Beukel CJ, Fievez L, Michels M, Sweep FC, Hermus AR, Bosch ME, et al. Vitamin D deficiency among HIV type 1-infected individuals in the Netherlands: Effects of antiretroviral therapy. AIDS Res Hum Retroviruses. 2008;24:1375-82.

26. Aparicio AMG, Fernández SM, González J, Arribas JR, Peña JM, Vázquez JJ, et al. Abnormalities in the bone mineral metabolism in HIV-infected patients. Clin Rheumatol. 2006;25:537-9.

27. Rodríguez M, Daniel SB, Gunawardene S, Robbins GK. High frequency of vitamin D deficiency in ambulatory HIV-positive patients. AIDS Res Hum Retroviruses. 2009;25:9-14.

28. Ford ES, Ajani UA, Mcguire LC, Liu S. Concentrations of serum vitamin $D$ and the metabolic syndrome among U.S. adults. Diabetes Care. 2005;28:1228-30.

29. Forouhi NG, Luan J, Cooper A, Boucher BJ, Wareham NJ. Baseline serum 25-hydroxy vitamin $D$ is predictive of future glycemic status and insulin resistance. The Medical Research Council Ely Prospective Study 1990-2000. Available from: http://diabetes.diabetesjournals.org. Access June 30, 2008. 